





\section{ZOOLOGICA}

SCIENTIFIC CONTRIBUTIONS OF THE NEW YORK ZOOLOGICAL SOCIETY

FROM THE TROPICAL RESEARCH

STATION IN BRITISH GUIANA

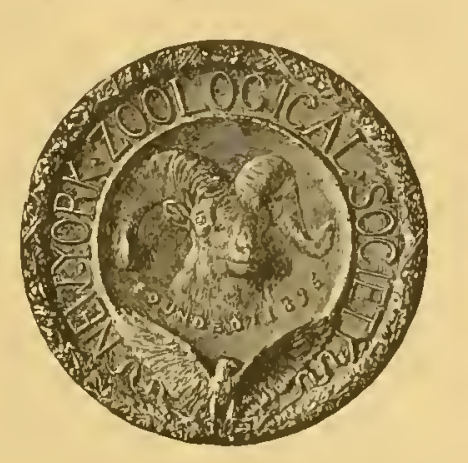

VOLUME III. NUMBER 11

(Tropical Research Station Contribution Number 105)

A NEW ENTOMOBRYA

By J. W. Folsom

P U B L I S H E D B Y THE S O C I E T Y THE ZOOLOGICAL PARK, NEW YORK

DECEMBER 24, 1921 



\title{
A NEW ENTOMOBRYA
}

\author{
By J. W. FOLSOM
}

Entomobrya wheeleri sp. nov:

(Fig. 18)

Head and body mottled with blue pigment, with no definite color pattern (Fig. 18a). Sternum white. Antennæ blue; first three segments darker apically. Coxæ slightly pigmented, also femora distally and tibiotarsi proximally. Furcula unpigmented. Eyes 8-8, on black patches, the two inner proxima: eyes of each side being smaller than the others. Antennæ one and three-fifths times as long as the head, with segments in relative lengths about as 9:22:19:30; basal ring large, resembling a segment. Mesonotum not projecting anteriorly. Fourtls abdominal segment almost five times as long as the third. Unguis (Fig. 18b) with a pair of lateral teeth and with two inner teeth, the proximal tooth being doubled. Unguiculus: three-fifths as long as the unguis. Furcula attaining the ventral tube. Manubrium and dentes subequal in length. Dentes crenulate dorsally. Mucrones (Fig. 18c) subequally bidentate, the basal spine being absent; two fringed setæ projecting from each dens extend almost to the end of each mucro. Corpus of tenaculum with a single curving ventral seta. General clothing of clense short setæ. Clavate, ringed setæ occur on the anterior part of the head, on the last abdominal segment, and on the dorsal region of the manubrium. Pointed, fringed setæ are present on the last two abdominal segments and on the furcula dorsaliy and ventrally. A few long, stout, fringed setæ occur on the antennæ, two or three on each coxa, a few on femur and tibiotarsus, and several on the anterior surface of the ventral tube. Length $1 \mathrm{~mm}$.

The preceding description applies only to the largest specimen as regards proportions and pigmentation, for these characters vary according to the age of the individual, as usual. Thus in a specimen $0.39 \mathrm{~mm}$. in length, there is scarcely any blue pigment, the fourth antennal segment being, however; 

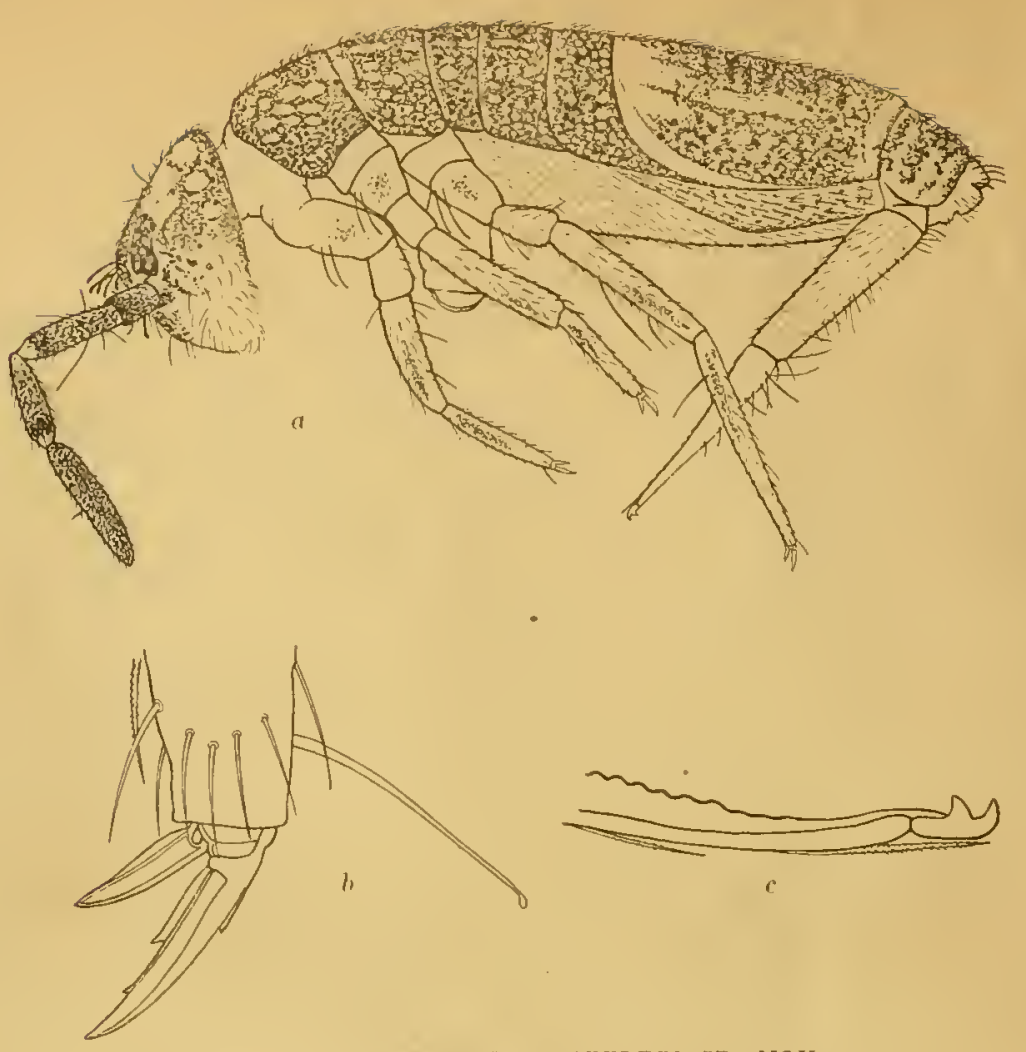

FIG. 18. ENTOMOBRYA WHEELERI SP. NOV.

$a$, lateral view, X $41.5 ; b$, left hind foot, $\mathrm{X} 386 ; c$, left mucro, $\mathrm{X} 386$.

faintly tinged apically with blue; the eyes are pigmented separately instead of collectively; the antenrix are subequal to the head in length, with segments short and stout, in relative lengths as $4: 5: 5: 11$; while the fourth abdominal segment is only two and two-thirds times as long as the third. In an individual 0.6 $\mathrm{mm}$. in length, the ratio between the third and fourth abdominal segments is as $1: 4$.

Described from four cotypes, which have been deposited in the Museum of Comparative Zoology, Cambridge, Mass.

I take pleasure in naming this new collembolan after Professor W. M. Wheeler, who found it living with colonies of a peculiar social beetle, Coccidotrophus socialis Schwarz and Barber, at Kartabo, in British Guiana. 





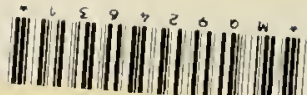

